\title{
Effect of Blanching on Saponins and Nutritional Content of Moringa Leaves Extract
}

\author{
Yuanita Indriasari ${ }^{1}$, Wignyanto ${ }^{2} \&$ Sri Kumalaningsih $^{2}$ \\ ${ }^{1}$ Magister Program of Agroindustry Technology, Faculty of Agricultural Technology, University of Brawijaya, \\ Malang, East Java, Indonesia \\ ${ }^{2}$ Faculty of Agricultural Technology, University of Brawijaya, Malang, Indonesia \\ Correspondence: Yuanita Indriasari., Magister Program of Agroindustry Technology, Faculty of Agricultural \\ Technology, University of Brawijaya, Malang, East Java, Indonesia. E-mail: arbainah_60@yahoo.co.id
}

Received: March 22, 2016 Accepted: April 25, 2016 Online Published: May 16, 2016

doi:10.5539/jfr.v5n3p55 URL: http://dx.doi.org/10.5539/jfr.v5n3p55

\begin{abstract}
Moringa oleifera leaves have been used as food material because it has high nutritional value. Many research have been conducted on moringa leaves extract as functional food and the additional material of nutrient for some food products (biscuit, bread, jelly drink), which it looked that adding moringa leaves extract above 5\% decrease the consumer acceptance level toward the product because of the strongest unpleasant aroma and bitter taste, which is caused by saponins content in moringa leaves extract is still high enough. The aim of the research is to determine the optimum time and temperature of blanching process of moringa leaves in order to decrease its saponin content and at the same time to preserve its nutritional content. Blanching process used temperature 85 ${ }^{\circ} \mathrm{C}$ for 7.5 minutes can decrease saponins content of moringa leaves to the lowest content amount $3.9 \%$, but still preserve protein content amount $25.08 \%$, vitamin C content amount $84.68 \mathrm{mg} 100 \mathrm{~g}-1$ and increase vitamin A amount $3600 \mu \mathrm{g} 100 \mathrm{~g}-1$.
\end{abstract}

Keywords: moringa leaves, moringa oleifera, blanching, saponins

\section{Introduction}

Moringa leaves flour has a high nutritional compound and can be used as a functional food ingredient. According to Fuglie (2001), just take $8 \mathrm{~g}$ powder of moringa leaves per day can give nutrient to baby (1-3 years old), namely $14 \%$ protein, calcium $23 \%$, iron and almost all needs of vitamin A. Meanwhile, in $100 \mathrm{~g}$ moringa leaves powder can contribute more than $1 / 3$ of calcium, iron, protein, cuprum, sulphur and vitamin B of women of childbearing age. Most of research has been done to develop functional food that enriched with the flour of moringa leaves or moringa leaves extract. From the research showed that adding the flour of moringa leaves can increase the nutritional value of the food material, but in organoleptic that food product is less interesting because of unpleasant aromatic and bitter taste from moringa leaves flour that influence consumer acceptance (Kholis \& Hadi, 2010; Sengev et al., 2013; Yulianti, 2008).

At moringa leaves, unpleasant aromatic is caused by metabolite secondary component namely saponins. Saponins constitute steroid or triterpenoid glucoside that is bounded at carbohydrate. Saponins cause bitter taste, having characteristic in the form of foam and can dissolve in water easily. According to Mackar and Becker (1996), there are $81 \mathrm{~g} / \mathrm{kg}$ saponins at fresh moringa leaves. Bitter taste and unpleasant aromatic emerged by saponins influence consumer acceptance level to the food product that is fortified with moringa leaves extract. It means that to increase the acceptance of food product that is enriched with moringa leaves flour, the unpleasant aromatic and bitter taste must be decreased, or the same as decrease saponins content at moringa leaves before extracted.

According to Nkafamiya et al. (2006), Adeboye and Babajide (2010) in their research, it is stated that some antinutrition compound as oxalic acid, tannins, $\mathrm{HCN}$ and saponins that contain at the vegetable can be decreased by blanching process, especially when the process using boiled water. But there is no specific research about declining saponins content on moringa leaves using blanching process.

It is necessary to remember that thermal process such as blanching can decrease nutritional content from the material, especially the component that is susceptible to high temperature and dissolved in water easily such as 
protein and vitamin C. According to Fuglie (2001), moringa oleifera leaves have a high amount of protein and vitamin $\mathrm{C}$ content. So related to this case, the aim of this research is to determine the temperature and time of blanching process in order to decrease saponins content, but still keeping the nutritional damage of moringa leaves at minimum level.

\section{Matericals and Methods}

\subsection{Materials}

This research used moringa leaves that were obtained from the moringa plants grow in Biromaru, Sigi District, Central Sulawesi Province. The characteristic of moringa leaves used is dark green, commonly the size is 1.2-2 $\mathrm{cm}$ and the wide is $0.6-1 \mathrm{~cm}$, also oval shape. The other materials such as ethanol $96 \%$ and aquadest, were obtained from the local shop. The proximate and nutritional analysis conducted at Tadulako's University Agrotechnology Laboratory.

\subsection{Methods}

\subsubsection{Blanching Process}

This research is used randomized complete block design, with temperature variable as the first factor $\left(75^{\circ} \mathrm{C}, 85\right.$ ${ }^{\circ} \mathrm{C}$ and $95^{\circ} \mathrm{C}$ ) also time variable as the second factor ( 5 minutes, 7.5 minutes and 10 minutes). Every treatment is repeated three times. The choice of temperature treatment based on preliminary research, which has been conducted to determine the temperature and time of blanching process.

The first step of this research is declining saponins content on moringa leaves using blanching process. Two hundred (200) grams of moringa leaves was prepared, then it is blanched in $600 \mathrm{ml}$ water, at the temperature and time that suitable with the treatment. To keep the decline of nutritional value is not too high, the blanching process is done on temperature less than $100{ }^{\circ} \mathrm{C}$ at a time less than 10 minutes. Beside that, the process of filling moringa leaves in boiled water is done exactly when the temperature has reached the temperature treatment so it can minimize the contact between moringa leaves and boiled water. After blanched, it is drained for 5 minutes. And then blanched moringa leaves dried using vaccum cabinet dryer at the temperature $60-70{ }^{\circ} \mathrm{C}$ for $2-4$ hours. After that analyzed the protein, vitamin $\mathrm{C}$, vitamin $\mathrm{A}$ and saponins content. Final step is determining the optimum treatment (temperature and time) that can decrease saponins content on moringa leaves to the lowest level, but still preserve nutritional content of moringa leaves.

\subsubsection{Extracting Process}

The second step of this research is extracting nutritional content on blanched moringa leaves (optimum treatment) using maceration method. The steps are crushed $200 \mathrm{~g}$ of blanched moringa leaves by using blender, then it measured again. And then it macerated separately with ethanol $70 \%(1: 20 \mathrm{w} / \mathrm{v})$ for 72 hours at room temperature $\left(28 \pm 2{ }^{\circ} \mathrm{C}\right)$, and it shaked occasionally. The extract is filtered using filtered paper (Whatman 42 ), and it's residue extracted again by using the same process and solvent until it became surfeited. After that analyzed the protein, vitamin $\mathrm{C}$, vitamin $\mathrm{A}$ and saponins content.

\subsubsection{Chemical Analyses}

The chemical composition analysis was determined by AOAC series method (Horwitz et al., 2010): vitamin A by AOAC official method number 992.04, vitamin C (AOAC number 984.26), protein content (AOAC number 967.12). Saponins content measured using spectrophotometer-uv method, with stages as follow: $0,1 \mathrm{~g}$ dry leaves up to constant weight then it crushed with mortal until it became smooth powder, after that it is dissolved in 10 $\mathrm{ml}$ ethanol $70 \%$ in reaction tube. The powder is extracted in bath on $180^{\circ} \mathrm{C}$ within 15 minutes. Absorbency of the extracted result was measured by using spectrophotometer uv- vis on the length of wave $365 \mathrm{~nm}$ and used saponin Merck as standard solution. Concentration value read was saponin level (Stahl, 1985).

\subsubsection{Statistical Analysis}

The data obtained was subjected to statistical Analysis of Variance (ANOVA) (Steel \& Torrie, 1991), and the significant difference among the means was compared with the Duncan's Multiple Range Test (DMRT) with a probability $\mathrm{p} \leq 0.05$.

\section{Results and Discussion}

\subsection{Characteristic of the Moringa Leaves (Fresh)}

The moringa leaves that used in this research were taken from Biromaru, Sigi District, Central Sulawesi Province. There is no scientific record about the chemical characteristic of fresh moringa leaves from that area, so it is important to do the identification of chemical characteristic because the value of it really depends on the 
plants growth area or the type of the soil. The chemical characteristic of fresh moringa leaves that is used in this research can be seen at Table 1 .

Table 1. Chemical characteristic of fresh moringa leaves

\begin{tabular}{|c|c|c|c|c|c|c|c|}
\hline \multirow{3}{*}{ Materials } & \multicolumn{7}{|c|}{ Characteristics } \\
\hline & \multicolumn{4}{|c|}{ Proximate } & \multicolumn{3}{|c|}{ Nutritional } \\
\hline & $\begin{array}{c}\text { Water } \\
(\%)\end{array}$ & Ash (\%) & $\begin{array}{l}\text { Protein } \\
(\%)\end{array}$ & Fat $(\%)$ & $\begin{array}{c}\text { Fiber } \\
(\%)\end{array}$ & $\begin{array}{l}\text { Vitamin C } \\
\left(\mathrm{mg} 100 \mathrm{~g}^{-1}\right)\end{array}$ & $\begin{array}{l}\text { Vitamin A } \\
\left(\mu \mathrm{g} 100 \mathrm{~g}^{-1}\right)\end{array}$ \\
\hline $\begin{array}{l}\text { Moringa } \\
\text { Leaves }\end{array}$ & 8.35 & 8.33 & 26.36 & 8.53 & 12.72 & 189.56 & 2800 \\
\hline
\end{tabular}

The results show that the nutrition content of moringa leaves as basic commodity is high enough and can fulfill the nutrient needs. Based on Indonesian Health Minister Regulation number 75 of 2013 about the number of nutrient sufficiency that is suggested to some age levels proved that by consuming moringa leaves and adding the other food material hav fulfilled the need of protein, fibrous, vitamin A and vitamin C of Indonesian Society, especially in Palu District, Central Sulawesi Province.

\subsection{Blanching Process}

3.2.1 Saponins Content

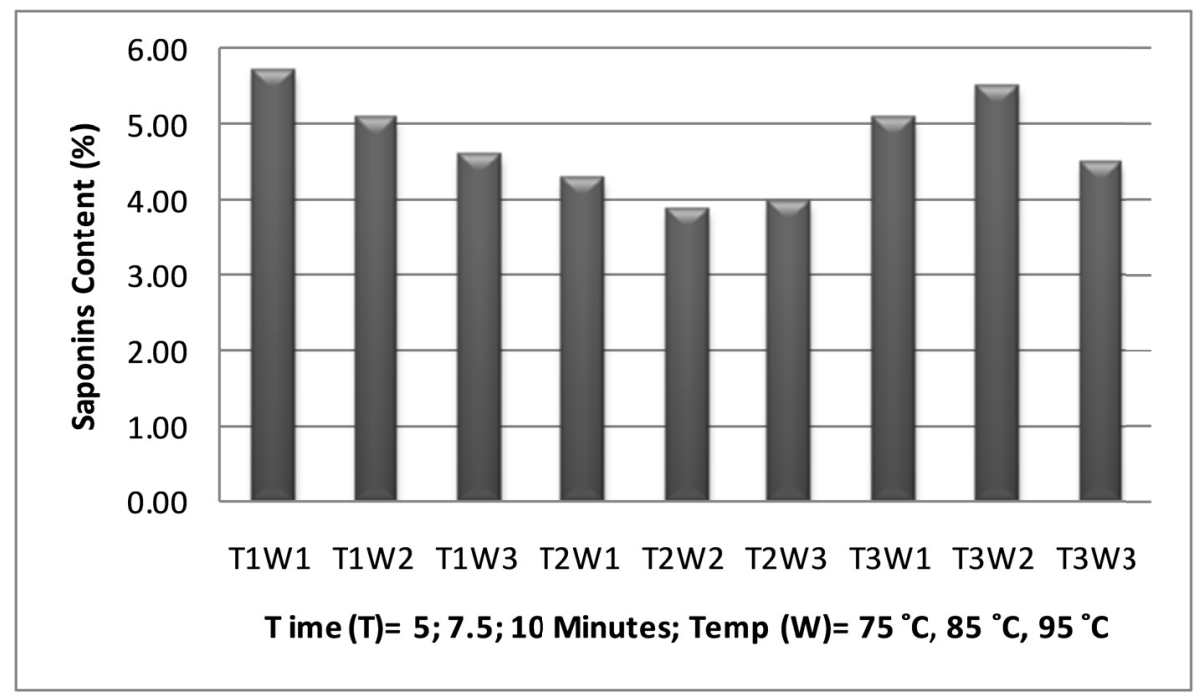

Figure 1. Saponins Content on Moringa Leaves Under Different Time and Temperature of Blanching Process

The research showed that saponins content of fresh moringa leaves was $6.5 \%$, and it decreased after blanching process, around $3.9 \%$ to $5.7 \%$. This result showed that the interaction between the temperature and time of blanching process that is applied on moringa leaves is not significantly influenced by saponins content, but it proved can decrease saponins. The difference of response is only caused by the temperature treatment given based on the Duncan Multiple's Range Test $(\alpha=5 \%)$ known that the difference of response on saponins content is showed by the temperature $85^{\circ} \mathrm{C}$ (treatment T2).

The lowest average of saponins content is $0.39 \%$, showed at blanching treatment using temperature $85{ }^{\circ} \mathrm{C}$ for 7.5 minutes (T2W2), whereas the highest average value of saponins content showed at blanching treatment using temperature $75{ }^{\circ} \mathrm{C}$ for 5 minutes (T1W1), which is $0.57 \%$. It also shows from the graphic, that the shape was upside parabola, means that the saponins content is higher in temperature $75{ }^{\circ} \mathrm{C}$, then it decrease to the lowest level in temperature $85{ }^{\circ} \mathrm{C}$, and at the temperature $95{ }^{\circ} \mathrm{C}$ the saponins content increase again. According to Ogbonnaya and Chinedum (2013), the blanching treatment by using boiled water in temperature $95-100{ }^{\circ} \mathrm{C}$ can 
softening the vegetable tissues so the water and the compound that contains in it can fill in osmosis because of the very high permeability of membrane. It causes the higher of saponins content on moringa leaves after blanched in the temperature $95{ }^{\circ} \mathrm{C}$. Based on that, to decrease saponins content on moringa leaves down to the lowest level, it needs a specific temperature and time of blanching process.

\subsubsection{Nutritional Content}

Table 2. Nutritional content on blanched moringa leaves under different time and temperature of blanching process

\begin{tabular}{lccc}
\hline \multirow{2}{*}{ Variable } & \multicolumn{3}{c}{ Test Parameters } \\
\cline { 2 - 4 } & Protein $(\%)$ & Vitamin $\mathrm{C}\left(\mathrm{mg} 100 \mathrm{~g}^{-1}\right)$ & Vitamin A $\left(\mu \mathrm{g} 100 \mathrm{~g}^{-1}\right)$ \\
\hline T1W1 (75 ${ }^{\circ} \mathrm{C}, 5$ Minutes $)$ & $26.39 \mathrm{bc}$ & $102 \mathrm{c}$ & $2633 \mathrm{a}$ \\
T1W2 $\left(75^{\circ} \mathrm{C}, 7.5\right.$ Minutes $)$ & $26.24 \mathrm{bc}$ & $98.5 \mathrm{bc}$ & $3700 \mathrm{ab}$ \\
$\mathrm{T} 1 \mathrm{~W} 3\left(75^{\circ} \mathrm{C}, 10\right.$ Minutes $)$ & $25.66 \mathrm{ac}$ & $88.7 \mathrm{ac}$ & $3467 \mathrm{ab}$ \\
$\mathrm{T} 2 \mathrm{~W} 1\left(85^{\circ} \mathrm{C}, 5\right.$ Minutes $)$ & $25.35 \mathrm{~b}$ & $85.53 \mathrm{bc}$ & $3500 \mathrm{a}$ \\
$\mathrm{T} 2 \mathrm{~W} 2\left(85^{\circ} \mathrm{C}, 7.5\right.$ Minutes $)$ & $25.08 \mathrm{~b}$ & $84.68 \mathrm{bc}$ & $3600 \mathrm{ab}$ \\
$\mathrm{T} 2 \mathrm{~W} 3\left(85^{\circ} \mathrm{C}, 10\right.$ Minutes $)$ & $24.74 \mathrm{ab}$ & $77.06 \mathrm{ab}$ & $3300 \mathrm{ab}$ \\
$\mathrm{T} 3 \mathrm{~W} 1\left(95^{\circ} \mathrm{C}, 5\right.$ Minutes $)$ & $23.39 \mathrm{ab}$ & $65.44 \mathrm{ac}$ & $3333 \mathrm{a}$ \\
$\mathrm{T} 3 \mathrm{~W} 2\left(95^{\circ} \mathrm{C}, 7.5\right.$ Minutes $)$ & $23.26 \mathrm{ab}$ & $59.24 \mathrm{ab}$ & $3400 \mathrm{ab}$ \\
$\mathrm{T} 3 \mathrm{~W} 3\left(95^{\circ} \mathrm{C}, 10\right.$ Minutes $)$ & $22.59 \mathrm{a}$ & $54.87 \mathrm{a}$ & $3400 \mathrm{ab}$
\end{tabular}

Note : Different letters in columns are significantly different $(\mathrm{p}<0.05)$ in Duncan's Multiple Range Tests

The result shows that protein content on moringa leaves after it blanched about $22.59 \%$ to $26.39 \%$, known that the higher the temperature and the longer the time of blanching process, can make the protein content on moringa leaves become lower. Based on the Duncan's Multiple Range Test $(\alpha=5 \%)$, the difference of response is caused by both the temperature and time of blanching process.

Heating process such as blanching, can cause the denaturation of protein. It means that the structure change because the hydrogen bounding is opened, so it cause the ability of protein to bound with water decreased and a part of protein coagulated, precipitated and wasted with the water (Winarno, 1993). So it is important to search for a better temperature and time for blanching process, in order to minimize the denaturation of protein content.

The derivation on protein content because of the blanching process in this research is also showed by some other researchers (Hefnawy, 2011; Mepbha et al., 2007; Mutiara et al., 2013; Nkafamiya et al., 2010).

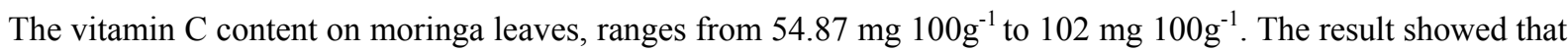
the interaction of the temperature and time of blanching process that applied at moringa leaves, influence significantly to vitamin C content. Based on the Duncan's Multiple Range Test ( $\alpha=5 \%$ ), known that the difference of response on vitamin $\mathrm{C}$ content caused by both the temperature and time of blanching process. The result showed that the value of vitamin $\mathrm{C}$ decrease in compliance with the increasing of temperature and time. According to Nambiar et al. (2001), the decreasing on vitamin C content caused by the characteristic of vitamin $\mathrm{C}$ that can dissolve in the water easily and it is not stable in the high temperature.

Vitamin A is a group of vitamin that can dissolve in fat and commonly endure to hot. The vitamin A content on moringa leaves, ranges from $2633 \mu \mathrm{g} 100 \mathrm{~g}^{-1}$ to $3700 \mu \mathrm{g} 100 \mathrm{~g}^{-1}$. The treatment T1W2 (temperature $75{ }^{\circ} \mathrm{C}$ for 7.5 minutes) showed the highest amount of vitamin A, which is $3700 \mu \mathrm{g} 100 \mathrm{~g}^{-1}$. Based on the Duncan's Multiple Range Test $(\alpha=5 \%)$, known that the difference of response on vitamin A content only caused by the time of blanching process. It means that the time of blanching process, can influence the value of vitamin A on moringa leaves. The longer the time of blanching process can cause the decreasing of vitamin A content on moringa leaves. Dutta et al (2004), said that more longer the duration and more higher the temperature of blanching process can cause the derivation of carotene content because it can releasing the bounded and carotene can dissolved easily in the water. 
This research also showed that the blanching process can increase the value of vitamin A content on moringa leaves, compared to vitamin A content on fresh moringa leaves. According to Howard et al (1999), the carotene (vitamin A) on a plant is bounded with protein, the heat treatment such as steaming, cooking and blanching can release the carotene that bounded, so it can extracted and digested easily.

\subsection{Extraction Process}

According to Ndong et al (2007), the content of protein in moringa leaves can reach $35 \%$, but the digestibility of protein is low about $56.1 \pm 8.9 \%$, because the protein is bounded at carbohydrate (fibrous), which is so high its content at moringa leaves. To increase the absorptive capacity of nutrition in the body, can be done by extracting the nutrition.

Various extraction methods can be done to extract the nutrition from moringa leaves. Vongsak et al (2013) reported that the maceration method with ethanol $70 \%$ is the extraction method that is good for moringa oleifera, because it produces high rendemen crude extract, produce high phenol content, flavonoid and the highest prominent active component, also highest activity of oxide resistance. Based on it, the extraction method used on this research was maceration with ethanol $70 \%$, in order to get the moringa leaves extract. The chemical characteristic of the moringa leaves extract showed at Table 3.

Table 3. Chemical characteristic of moringa leaves extract

\begin{tabular}{|c|c|c|c|c|}
\hline \multirow[b]{2}{*}{ Materials } & \multicolumn{4}{|c|}{ Chemical Characteristic } \\
\hline & Protein $(\%)$ & $\begin{array}{l}\text { Vitamin C } \\
\left(\mathrm{mg} 100 \mathrm{~g}^{-1}\right)\end{array}$ & $\begin{array}{l}\text { Vitamin A } \\
\left(\mu \mathrm{g} 100 \mathrm{~g}^{-1}\right)\end{array}$ & Saponins (\%) \\
\hline $\begin{array}{c}\text { Moringa Leaves } \\
\text { Extract }\end{array}$ & 16.25 & 64.49 & 0 & 3.7 \\
\hline
\end{tabular}

The result showed that the value of protein and vitamin $\mathrm{C}$ are decrease significantly, even more there are no vitamin $\mathrm{A}$ on the moringa leaves extract. It is because proteins and vitamin $\mathrm{C}$ are sparsely soluble in $70 \%$ ethanol and hence are not expected in large amounts in an ethanolic extract. Vitamin A is insoluble both in water and in ethanol. On the other hand for saponins content showed a non significant decrease, it is because saponins are effectively extracted into 70 or $80 \%$ ethanol.

\section{Conclusion and Recommendation}

Blanching proved to reduce saponins content on moringa leaves. Blanching process at temperature $85{ }^{\circ} \mathrm{C}$ for 7.5 minutes proven as the best treatment, in order to decrease saponins content on moringa leaves till the lowest level, but still able to maintain the nutritional value. Blanching is one of the most possible strategies for preservation of Moringa oleifera leaves, which are highly seasonal and perishable. The abundantly available inexpensive leaves of $M$. oleifera can serve as a pool house of nutrients and can be used in the developing countries to combat micronutrient deficiencies.

Blanching alone is not enough process to consume moringa leaves immediately. The scope of the study should emphasize that blanching is done as pre-treatment for processing. Changes in nutritional value may still occur depending on the process done after blanching of moringa leaves. Thus, it should have been recommended to analyze nutritional characteristic changes when moringa leaves are processed in different methods.

\section{Acknowledgement}

We are thankful to Polytechnic of Palu and Brawijaya University providing convenience in using the experimental equipments and for the financial support of the Directorate General of Higher Education.

\section{References}

Adeboye, A. S., \& Babajide, J. M. (2010). Effect of Processing Methods on Antinutrients in Selected Leafy Vegetables. Nigerian Food Journal, 25, 77-87. http://dx.doi.org/10.4314/nifoj.v25i2.50843

Dutta, D., Utpal, R., \& Runnu, C. (2004). Retention of Beta-carotene in Frozen Carrots Under Varying Conditions of Temperature and Time of Storage. Retrieved August 8, 2015, from www.academicjournal.org/ajb/PDF 
Fuglie, L. J. (2001). The Miracle Tree: Moringa oleifera: Natural Nutrition for the Tropics. Training Manual. Church World Service, Dakar, Senegal. Retrieved August 8, 2015, from www.moringatrees.org/moringa/miracletree.htm

Hefnawy, T. H. (2011). Effect of Processing Methods on Nutritional Composition and Anti-Nutritional Factors in Lentils (Lens culinaris). Annals of Agricultural Science, 56(2), 57-61. http://dx.doi.org/10.1016/j.aoas.2011.07.001

Horwitz, W., \& Latimer, G. Jr. (2010). Official Methods of Analysis of AOAC International - 18th Edition, Revision 3. Thomson Reuters Chicago, USA.

Howard, L. A., Wong, A. D., Perry, A. K., \& Klein, B. P. (1999). $\beta$-Carotene and Ascorbic Acid Retention in Fresh and Processed Vegetables. Journal of Food Science, 64(5), 929-936.

Kholis, N., \& Fariz, H. (2010). Bioassay Testing of Infant Biscuit Supplemented with Moringa Leaf Protein Concentrate in Model of Malnutrition Rat. Agricultural Technology Journal, 3(11), 144-151.

Mackar, H. P. S., \& Becker. (1996). Nutritional Value and Antinutritional Component of Whole and Ethanol Extracted Moringa Oleifera Leaves. Journal of Feed Science and Tecnology, 63, 211-228.

Mepba, H.D., L. Eboh \& D.E.B. Banigo. (2007). Effects Of Processing Treatments On The Nutritive Composition And Consumer Acceptance Of Some Nigerian Edible Leafy Vegetables. African Journal of Food Agriculture Nutrition and Development, 7(1), 1-18.

Mutiara, K., Titi, H., Estiasih, T., \& Endang, S. (2013). Effect of Blanching Treatments against Protein Content and Amino Acid Drumstick Leaves (Moringa oleifera). Journal of Food Research, 2(1), 101-108.

Nambiar, \& Seshadri, S. (2001). Bioavailability of Beta Carotene From Fresh And Dehydrated Drumstick Leaves In A Rat Model. Journal of Plant Foods for Human Nutrition, 56(1), 83-95.

Ndong, M., Guiro, A. T., Gning, R. D., Idohou-Dossou, N., Cisse, D., \& Wade, S. (2007). In Vitro Iron Bioavailability and Protein Digestibility of Traditional Senegalese Meals Enriched with Moringa oleifera Leaves Powder. University Cheikh Anta Diop Dakar, Senegal.

Nkafamiya, I. I., Manji, A. J., Modibbo, U. U., \& Umaru, H. A. (2006). Biochemical Evaluation of Casspourea congoensis (Tunti) and Nuclea latifloia (Luzzi). Fruits. African Journal Biotechnol, 6(19), 2461-2463.

Nkafamiya, I. I., Oseameahon, U. U. M., \& Haggai, D. (2010). Vitamins And Effect Of Blanching On Nutritional And Antinutritional Values Of Non-Conventional Leafy Vegetables. African Journal of Food Science, 4(6), 335-341.

Ogbonnaya, E. C., \& Chinedum, E. K. (2013). Bioactive Constituents and In vitro Antioxidant Capacity of Water Leaf (Talinum triangulare) as Affected by Domestic Cooking. European Journal of Medicinal Plants, $3(4), 540-551$.

Sengev, A. I., Joseph, O. A., \& Dick, I. G. (2013). Effect of Moringa oleifera Leaf Powder Supplementation on Some Quality Characteristics of Wheat Bread. Journal of Food and Nutrition Science, 270-275.

Stahl, E. (1985). Drug Analysis by Chromatography and Microscopy. Translator : Padmawinata, K and I. Sudiro. Bandung: ITB Publisher.

Steel, R. G. D., \& Torrie, J. D. (1991). Principles and statistical procedures (3rd ed.).

Vongsak, B., Pongtip, S., Supachoke, M., Suchitra, T., Yuvadee, W., \& Wandee, G. (2013). Maximizing Total Phenolics, Total Flavonoids Content and Antioxidant Activity of Moringa oleifera Leaf Extract by The Appropriate Extraction Method. Journal of Industrial Crops and Products, 44, 566-571.

Winarno, F. G. (2003). Food, Nutrient and Consumer. PT. Gramedia, Jakarta.

Yulianti, R. (2008). Making The Moringa Leave Jelly Drink as a Source of Vitamin C and $\beta$-Carotene (Unpublished master's thesis). Bogor Agricultural Institute, Bogor, West Java.

\section{Copyrights}

Copyright for this article is retained by the author(s), with first publication rights granted to the journal.

This is an open-access article distributed under the terms and conditions of the Creative Commons Attribution license (http://creativecommons.org/licenses/by/3.0/). 